\title{
Japan's transport planning at national level, natural disasters, and their interplays
}

\author{
Takeru Shibayama $^{1}$ (D)
}

Received: 21 October 2016 / Accepted: 28 June 2017 / Published online: 4 August 2017

(C) The Author(s) 2017. This article is an open access publication

\begin{abstract}
This research aims to give an overview of Japan's national-level transport planning schemes, and to discuss interplays between them and recoveries from natural disasters. In the first part, Japan's national spatial development plans and long-term planning schemes for railway, road, port and airport infrastructures are reviewed and compared. In the second part, imbalance embedded in the current planning scheme for different modes are demonstrated making use of recent post-disaster reconstruction processes. A literature-based desktop research is carried out focusing on Japanese literature. These include, but not limited to, official government reports and planning documents, statistical data, and handbooks for experts in the field. All of the long-distance modes have their planning schemes with different levels of comprehensiveness and robustness for each mode. Expressways and high-speed railways have the most comprehensive and robust network plans, while conventional railway, airports and seaports have ones with limited extent. Because of this, post-disaster reconstruction processes from damages to the infrastructure work differently in particular for conventional railways and for expressways in rural areas, which are competitors against each other. Strong framework for intermodal and multimodal transport is still in lack in Japan. Important structural imbalance between modes, in particular between conventional railway and expressway exist, and it becomes obvious in case of a
\end{abstract}

This article is part of Topical Collection on The development of National Transport Policy

Takeru Shibayama

takeru.shibayama@tuwien.ac.at

1 Research Center of Transport Planning and Traffic Engineering, Vienna University of Technology, Karlsplatz 13/230-1,

A-1040 Vienna, Austria natural disaster. Multimodal planning, frameworks for flexible adjustment of once-made long-term plans, and addressing imbalances regarding robustness between railways and expressways are identified as future challenges of the country's planning schemes.

Keywords Japan · Transport master plan · Historical development $\cdot$ Natural disaster

\section{Introduction}

This paper aims firstly to gain a comprehensive overview of Japan's national-level transport planning schemes as well as overarching long-term plans closely related to them. The second aim of this paper is, with recent examples, to demonstrate interplays between different long-term planning schemes set for each of the transport modes and the consequences of natural disasters. Here, the term "transport planning scheme" refers to a composition of legislature, official governmental documents, and plans resolved or approved by the Diet, the Cabinet or minister(s), which frames directionality of the future infrastructural development of transport in the country.

Japan has extensive nationwide transport infrastructures for long-distance transport as well as urban and regional transport. At the time of writing this paper, in Japan, c.a. $20,100 \mathrm{~km}$ of national railway network (Japan Railway - JR, including conventional and high-speed railways) is offered. The road network extends to approximately 1.2 million $\mathrm{km}$, including expressways $(7641 \mathrm{~km})$ and national highways $(54,736 \mathrm{~km})$ as well as prefectural roads (approx. 130,000 km) and municipal roads (about 1 million $\mathrm{km}$ ) as of 2009. The country has 97 airports and 994 ports. These have been gradually developed since Japan's industrialization in the late nineteenth century, 
especially in the period after World War II, when the country experienced a rapid economic growth [1-4].

At the same time, transport infrastructure is repeatedly damaged by various types of natural disasters. Not only the earthquake and the tsunami that many people would associate with Japan nowadays, but also other types of natural disasters such as typhoons, floods, storm surges, volcano eruptions, landslides, and avalanches happen relatively frequently throughout the country with some seasonal tendencies. Earthquakes, tsunamis, typhoons and floods are the typical natural disasters that affect the land transport infrastructure to a larger extent compared to the other types of natural disasters, not only by direct damages triggered by the natural disaster but also through the reconstruction process afterwards. Unlike plannable national events that Japan often makes use of as target completion timings of infrastructural developments such as the Olympic Games, natural disasters and ensuing damage to infrastructure cannot be planned for in the same way. To be sure, it is possible to prepare for such events to some extent in advance through disaster mitigation measures; however, it is an actual severe natural disaster that calls for acute planning and reorganization of the transport infrastructure. This is where preparedness and the robustness of the long-term transport planning schemes for different transport modes are tested.

This paper is structured as follows: after a short section on literature review (Section 2), a brief summary of Japan's developments in the post-war period is presented for those who are not familiar with the country's modern history (Section 3). Following these, an extensive review of national-level transport planning scheme is carried out (Section 4). As little literature and information is available elsewhere in English, detailed information is presented in this part, consequently making this part lengthy: readers familiar with Japanese planning schemes may skip this part; however, this forms a basis for the next sections. In Section 5, a comparison among the planning schemes for different transport modes is carried out. The imbalance between the planning schemes of the land-based modes are demonstrated making use of the cases triggered by natural disasters in Section 6, while Section 7 provides the conclusion.

The focus is set mainly on the post-war period until today; this is because the rapid development of the country and the transport infrastructure that makes up the backbone of the country was realized during this period. However, when necessary to understand the background or the context, the reference goes back to the earlier period.

\section{Existing literature on Japanese planning scheme}

Although a number of technical and historical materials have been published in the Japanese language for each mode of transport (e.g. [5, 6] for roads, [7, 8] for airports, [9-11] for railway, and [12] for sea routes), few literature dealing with an overview of the Japanese transport planning system covering all of the major modes at a national level exists. Many of the existing ones that are easily available are fragmented by mode, and clear overviews rarely exist.

Some authors tried to review development and transition of national land planning (e.g. [13]) or urban planning (e.g. [14]), but these analyze the changes of regional or urban planning in detail, and transport planning only appears as parts of them. The website of Ministry of Land, Infrastructure, Transport and Tourism (MLIT) has much information, while it is often segregated by mode and it is still not easy to gain an overview of the current system. It is easy to imagine that historical changes are more difficult to be understood with the ministry's website.

Impacts from the natural disasters on transport infrastructure are summarized by many, mostly into online resources, while these tend to remain hobbies or a sort of travelogues (e.g. [15] for roads and [16] for railway). Much literature focuses on consequences of single natural disasters, especially the 1923 Great Kanto Earthquake. However, such research tends to focus on general socio-political consequences in a context of rapidly-developing Tokyo (e.g. [17, 18]). To the best of the author's knowledge, there is none focusing on interplays between the impacts of natural disasters and the national transport planning process.

On top of this, the available literature mentioned above is in the Japanese language. It is difficult to access such information without knowing Japanese, including many technical and historical terms. In the English language, there is a clear lack of available information, especially an overview of current planning schemes as well as the historical development of them. This paper aims to fill this gap by providing such information about the developments of Japanese transport planning schemes at the national level including transport master plans in the English language, and to make a first attempt to analyze interplays between natural disasters, which happens frequently in Japan, and transport planning.

\section{Japan in the industrial age $-\mathbf{A}$ brief overview}

In the period between 1603 and 1868, Japan experienced a long-term stability under the Tokugawa shogunate's feudal system. During this period, a market economy, domestic trading by coastal sea routes as well as ports, inland long-distance footpaths connecting major cities with stations along them, as well as river transport were much developed. The capital, Edo (today's Tokyo), is estimated to have had more than a million inhabitants by around 1721. (See e.g. [19]).

Japan started its industrialization soon after the Meiji Restoration in 1868, when the leaders of the Meiji 
government aimed to catch up to the West by introducing Western technologies and socioeconomic institutions to the country. Railway, road and port infrastructures were developed by the state, as well as other infrastructures such as electricity and water resources. This trend continued until World War II, when the war destroyed much of these once-developed infrastructures. After defeat in 1945, Japan was under the US occupying forces, and in 1952 sovereignty was returned as the Treaty of San Francisco came into force.

Since then, Japan experienced rapid economic development with more than $10 \%$ of annual GNP (Gross National Production) growth for about 20 years between 1954 and 1973. This was supported by many different factors, including but not limited to the Income Doubling Economic Plan, a Keynesian economic policy in the 1960s, as well as many of the economic development programs under national-level development plans (see section 4.2). This was the time when the entire population and especially urban populations in industrial centers such as ChibaTokyo-Yokohama conurbation were growing rapidly, too. Since the 1980s, the population growth slowed down, and since the 1990s the total population has been stagnating and rapidly aging as shown in Fig. 1.

Regarding politics, post-war Japan had long been under the so-called Regime 1955 (55-nen Taisei): under this regime, the Liberty and Democratic Party (LDP) was in the ruling position, and the Social Party (later Social Democratic Party) was the second largest. This continued for about 40 years, and in the mid-1990s, there was a short period of non-LDP government. Then, there were a long period in which the LDP and the Komeito party formed coalitions. In 2009, the Democratic Party, established in 1998, formed the government as a coalition with smaller parties, but in 2012 the LDP-Komeito coalition came back to the ruling position. At large, Japan for most of the post-war period has been ruled under the LDPled government.

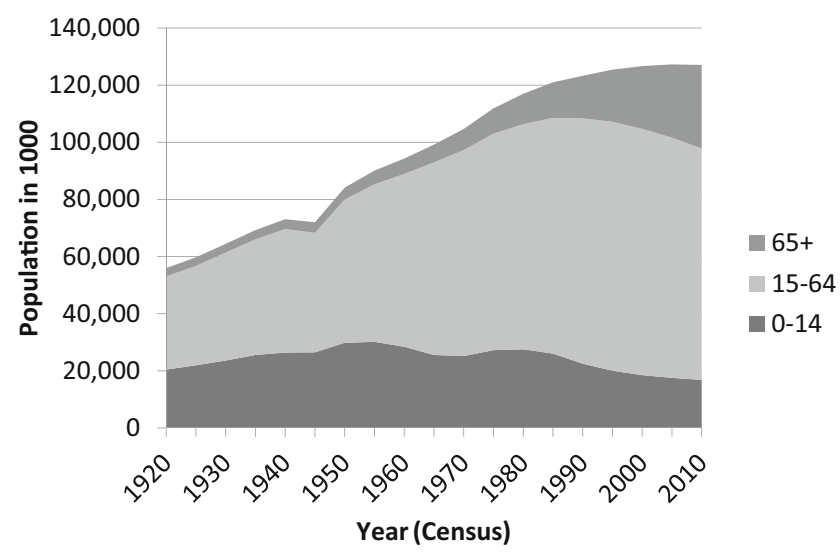

Fig. 1 Population in Japan in three age groups (own drawing based on [20])

\section{National-level transport planning scheme}

\subsection{Competences of ministries}

The responsibility for the railway was in the hands of the Ministry of Transport (Un'yu-sho) in the post-war period, which inherited administrative roles of the former Ministry of Railway. The Ministry of Transport was also responsible for maritime and air transport and thus for seaports and airports. The bus transport and tourism policies were also under the responsibility of this ministry.

The responsibility for the road infrastructure was in the hands of the Ministry of Construction (Kensetsu-sho) in the post-war regime. This ministry was also responsible for the management of rivers, housing, urban issues (e.g. sewage), because the ministry was created by dividing the former Ministry of Internal Affairs into several specialized ministries.

These two ministries were merged in 2001 together with the National Land Agency and the Hokkaido Development Agency, which were settled directly under the Cabinet Office. This was carried out as a part of the organizational restructuring of all of the ministries, and the Ministry of Land, Infrastructure, Transport and Tourism (MLIT) was established. For the first time, all competences related to transport and land development came under one roof.

\subsection{National-level spatial plans and its relevance to transport}

Japan's nationwide spatial and regional planning was officially set as the National General Development Plan (Zenkoku Sougou Kaihatsu Keikaku) in the post-war period. This is often referred to with its abbreviation Zenso. This scheme, which is stipulated by the National Land Development Act, started in 1950, and until 1998 five Zensos were officially approved with an approximately 10 -year interval. The responsibility was first in the hands of Economic Planning Agency (Keizai-kikaku-cho, EPA) until it was handed over to the National Land Agency (Kokudo-cho, NLA), which was newly established in 1972. Both EPA and NLA were directly settled under the Cabinet Office.

A new scheme was introduced in 2005 and the National Land Formation Plan (Kokudo Keisei Keikaku, NLFP) replaced the roles of the Zenso. The focus was officially shifted from quantitative growth to a qualitative improvement. The first and the second NLFPs were approved in 2008 and in 2015 respectively. The 2015 one is the latest one at the time of this research. MLIT is in charge of these.

The main goals and characteristics of the five Zensos as well as the two existing NLFPs are summarized in Tables 1 and 2 respectively. As seen in the tables, in the later Zensos as well as National Land Formation Plans, the key development method and strategy tend to become fairly abstract. Of note, 
Table 1 List and brief summaries of the Zensos, (Own translation based on [21])

\begin{tabular}{|c|c|c|c|c|c|}
\hline No & Year & Govt. agency & Main objectives & Target year & Key development method / strategy \\
\hline 1 & 1962 & EPA & $\begin{array}{l}\text { Developments balanced } \\
\text { among regions. }\end{array}$ & 1970 & $\begin{array}{l}\text { Decentralizing industrial locations, } \\
\text { developing new industrial centers }\end{array}$ \\
\hline 2 & 1969 & EPA & Creating enriched environment & 1985 & $\begin{array}{l}\text { Large projects such as Shinkansen and } \\
\text { Expressways to adjust regional balance }\end{array}$ \\
\hline 3 & 1977 & NLA & $\begin{array}{l}\text { Creating comprehensive and } \\
\text { integrated environment for } \\
\text { human lives }\end{array}$ & $\begin{array}{l}\text { "Approx. } 10 \text { years } \\
\text { since 1977" (1987) }\end{array}$ & $\begin{array}{l}\text { Regional developments to realize balances } \\
\text { among the regions and to create comprehensive } \\
\text { and integrated living environments }\end{array}$ \\
\hline 4 & 1987 & NLA & $\begin{array}{l}\text { Building multi-polar } \\
\text { decentralized land }\end{array}$ & $\begin{array}{l}\text { “Approx. } 12 \text { years } \\
\text { later" (around 2000) }\end{array}$ & $\begin{array}{l}\text { Networking within and among regions by (1) } \\
\text { infrastructures, (2) national development for } \\
\text { transport and communication infrastructures, } \\
\text { and (3) providing various networking possibilities. }\end{array}$ \\
\hline 5 & 1998 & NLA & $\begin{array}{l}\text { Basis for forming multi-axis } \\
\text { land structure }\end{array}$ & 2010-2015 & $\begin{array}{l}\text { (1) nature-rich living environments, (2) Urban } \\
\text { renovation of large cities, (3) Clusters among } \\
\text { regions, (4) Extensive internationally } \\
\text { networked area. }\end{array}$ \\
\hline
\end{tabular}

the fifth Zenso is titled differently; however, the legal basis, the responsible governing body, and the planning schemes of this fifth Zenso are unchanged from the previous ones. There is a document called "Grand Design of National Spatial Development towards 2050, Japan - Creation of a country generating diverse synergies among regions" published in 2014 by MLIT; this looks somewhat similar to NLFP, but practically this is a first draft for the second NLFP published in the following year, and thus does not count as an NLFP.

The Zenso typically indicates the general goals of transport infrastructure development, practically serving as an overarching transport masterplan. The Zenso often indicate routes or locations of important high-speed and conventional railway lines, expressways, ports, and airports to be constructed or upgraded within the next ten years. More detailed planning is carried out for each of the transport modes as seen in the following sections. The newer Zensos also deal with intermodal and multimodal transport briefly, although this does not have a well-structured planning scheme and the extent of the realization is limited.

\subsection{Planning of transport infrastructure}

\subsubsection{Railway in industrialized Japan - a brief review of the history}

The first railway in Japan constructed by British engineers went into service in 1872, four years after the Meiji Restoration, as a state-owned railway between Tokyo (Shimbashi) and Yokohama. The network was gradually extended towards the west and to the north, partly by private companies. The $1067 \mathrm{~mm}$ ( $3 \mathrm{ft} .6$ in.) narrow gauge ${ }^{1}$ was

\footnotetext{
${ }^{1}$ This is widely used in the former British colonies such as South Africa and New Zealand.
}

adopted and this eventually became the standard gauge in Japan. Much of the main lines that were privately built and operated were nationalized between 1906 and 1907. Further nationalization of smaller local private railways took place during World War II. The first high-speed line, known as Shinkansen, between Tokyo and Osaka was built by 1964 and it is considered to be the first high-speed railway in the world that regularly runs at over $200 \mathrm{~km} / \mathrm{h}$ [9-11].

\subsubsection{Conventional railway}

The first Railway Construction Act came into force in 1892 . This Act listed 33 main lines in it to be constructed to connect major cities on Honshu, Shikoku and Kyushu islands. For Hokkaido, a separate Hokkaido Railway Construction Act was put into force in 1896 for the same purpose. These acts were integrated and revised in 1922, and the list of the railway lines to be constructed (both main and regional railway lines) was moved to its annex. This annex was gradually extended over the time, and the Act itself was in force until 1987 when the Japan National Railway (JNR) was privatized and divided into six regional Japan Railways (JR) and one freight railway company. Until then, the above-mentioned legislatives had served as a sort of a blueprint or a kind of a masterplan of the conventional railway. Of note, in the later decades, it was considered to be fairly unrealistic to complete the listed railway as the extensive plan was made before the diffusion of automobiles. As such, it served more or less as a sort of a wish list rather than a realistic masterplan in the later decades. Since this Act went out of force in 1987, there is no comparable blueprint or a masterplan for the conventional railway at the national level.

Most of the listed lines that were actually constructed were under the management of the Ministry of Railway until the 1940s, then under Japan National Railway (JNR) and Japan 
Table 2 List and brief summaries of the national land formation plans at the national level (Own summary based on [22, 23])

\begin{tabular}{|c|c|c|c|c|}
\hline No. & Year & Agency & Main objectives & Key development method / strategy \\
\hline 1 & 2008 & MLIT & Autonomous growth of regions & $\begin{array}{l}\text { (1) Smooth networking with East Asia; } \\
\text { (2) Sustainability of regions; (3) Resiliency; } \\
\text { (4) Management of beautiful land; (5) Public } \\
\text { sphere towards collaboration in regional } \\
\text { development and management. }\end{array}$ \\
\hline 2 & 2015 & MLIT & $\begin{array}{l}\text { Promotion of socioeconomic " convection" } \\
\text { (This is named "basic planning concept.") }\end{array}$ & $\begin{array}{l}\text { To promote "socioeconomic convection:" (1) } \\
\text { Locally 'shining' and globally 'flying' land; } \\
\text { (2) Land management and infrastructure } \\
\text { supporting safety and economic growth; (3) } \\
\text { Participation and collaboration supporting } \\
\text { spatial planning; (4) Regional block's own } \\
\text { detailed plans (As appears in the summary } \\
\text { document by MLIT) }\end{array}$ \\
\hline
\end{tabular}

Railways (JR) after privatization, but a few exceptions exist. The construction of the listed railway lines was never complete. Rather, since the 1970s, closures of deficit-making regional railway lines of JNR have been sought. In the late 1980s, many such deficit-making regional railways were closed or transferred to newly-established local railway companies, often as joint ventures of the public and private stakeholders.

The opening of Shinkansen high-speed railways (see the next subsection) has affected the conventional railway largely since the 1990s. The ownership and operations of many of the conventional railway lines parallel to the Shinkansen lines that went into service after the 1990 s were transferred to newlyestablished regional railway companies, often established as publicly-owned enterprises or public-private joint ventures, because maintaining both conventional and high-speed lines is thought to create a severe financial burden for Japan Railways. As a matter of course, these kinds of publiclyowned or public-private enterprises face financial difficulties. This transfer scheme is based on a memorandum of understanding $(\mathrm{MoU})$ of the government and the JR in the early 1990s.

\subsubsection{High-speed railway (Shinkansen)}

The first high-speed railway between Tokyo and Osaka went into service in 1964 (Tokaido-Shinkansen). This was planned as a measure to double or even treble the capacity of the existing conventional railway line. This new line was built avoiding much of the residential and commercial areas along the existing conventional line, enabling quick construction and eventually making it suitable for a high-speed operation. It was designed technically independently from the conventional railway: the line was built with the $1435 \mathrm{~mm}$ international standard gauge, electrified with $25 \mathrm{kVAC}$, and structure and loading gauges larger than one used for the conventional railway. It was easy to justify the construction with this kind of argument given the rapid economic growth and the concentration of industry and population along the Tokyo-NagoyaOsaka corridor. The same argument was applied to the extension of this line to the west, Sanyo Shinkansen from Osaka via Hiroshima to Fukuoka (Hakata), which commenced service in 1972 (Osaka to Okayama) and in 1975 (Okayama to Fukuoka) [9, 24].

Soon after the opening of the Tokaido-Shinkansen, many ideas about nationwide Shinkansen networks were published, such as the one by JNR and the ruling party LDP. The planning of a high-speed railway network was brought into the Nationwide Shinkansen Railway Network Development Act in 1970 (Zenkoku Shinkansen-Tetsudo Seibi-hou). The objectives of this act are clearly stated in its Article 1 as follows:

This Act, considering the importance of the role of the high-speed passenger transport network contributing to the general and universal development of the country, aims to construct a nationwide railway network by Shinkansen in order to develop the national economy and to extend the life field of the citizen as well as to contribute to regional developments. (Article 1 "Purpose" of Zenkoku Shinkansen-Tetsudo Seibi-hou, translated by the author).

As such, the purpose of the Shinkansen high-speed railway already changed soon after the first line's opening from a measure for the capacity increase to a national development tool.

In this Act, the Minister of Transport are to publish the Base Plans to define the routes of Shinkansen railways whose constructions are to be started (Kihon-keikaku, Base Plans hereafter), which were published four times between 1971 and 1973. These Base Plans indicate approximate routes to be constructed as high-speed lines ${ }^{2}$ and thus the Act and the

\footnotetext{
${ }^{2}$ In this Act, the Shinkansen is defined as railways operated at $200 \mathrm{~km} / \mathrm{h}$ or faster on most parts of the lines.
} 
Base Plans together serve as a blueprint of the Shinkansen high-speed railway network.

Based on these Base Plans, more detailed Development Plans (Seibi-keikaku) are to be made. These are detailed implementation plans of each line, sometimes subdivided into several sections, and has to be agreed upon by the implementing body and the envisaged operator. Once a Development Plan is approved, a Construction Implementation Plan (Kouji-jisshi-keikaku) is made and the construction is budgeted. Six out of the seven routes defined in the first three Base Plans are either completed, under construction or in planning at the time of writing this paper as shown in Table 3. The one connecting Tokyo's main train station and Narita Airport, which is listed in the first Base Plan, is discontinued. Eleven other routes are listed in the fourth Base Plan, while, except for the 2nd Tokyo-Osaka route which will be constructed as the first JR Maglev, no detailed Development Plans have been made. This fourth Base Plan appears to be a sort of a wish list rather than a realistic master plan, similarly to the case of the conventional railway [25].

In the recent decades, the priority and the amount of investment for the constructions of new lines, as well as the financing framework and the timing of service inauguration are made in a form of a memorandum of understandings between the government (practically MLIT) and the ruling party. As the constellation of the two counterparts shows, the political will of the ruling party, which is often LDP, is much reflected. Although this is not in a legally-binding scheme, practically this sets the framework of the Shinkansen construction for the next decade. These are made so that the investment of approximately the next ten to fifteen years are framed, and thus this serves itself as the implementation plan for the high-speed railway network. Since 1990, at least five such agreements that specify these points have been made $[24,26]$.

\subsubsection{Road in industrialized Japan - A brief review of the history}

The base of the intercity road network was formed during the Edo period (1603-1868) well before the country's industrialization. During this period, intercity roads were designated mainly for horse-riding, walkers and a type of litter or palanquin known as Kago and Norimono, both carried by persons. Differently from Western countries, Japan did not experience a time when the horse carriage was widespread - in fact, the Tokugawa government restricted the use of wagons and carts until 1862 (see e.g. [27]). During the first phase of industrialization in the Meiji era, the first Road Act was approved in 1896 and technical standards were established in the following year. However, the focus of the intercity road was set more to military rather than civil transport purposes, and the railway played a more important role as the main means of intercity transport both for passengers and freight until the time soon after the end of World War II. The development of the road as a transport infrastructure took place primarily in the post-war period [6, 28] After World War II, with a few revisions, Japan's roads are categorized into the ones designated for general traffic (Douro-hou, "Road Act 1952" hereafter), and the other ones such as roads for forestry. The ones under the Road Act 1952 are classified into the following four groups [4]:

- Expressways: Roads making the key part of the nationwide network and connecting regions that are politically, economically, or culturally important;

Table 3 List of Shinkansens with Development Plan already made, Source: MLIT

\begin{tabular}{lllllll}
\hline Base plan & Name & Origin & Via & Destination & Length[km] & Status \\
\hline N/A & Tokaido-Sanyo & Tokyo & Osaka & Fukuoka & 1069 & In full operation \\
1st & Narita & Tokyo & - & Narita Airport & 65 & Discontinued \\
& Joetsu & Tokyo & Takasaki & Niigata & $270 *$ & In full operation \\
& Tohoku (southern part) & Tokyo & Sendai & Morioka & 675 & In full operation \\
2nd & Tohoku (northern part) & Morioka & Hachinohe & Aomori & 179 & In full operation \\
& Hokkaido & Aomori & Hakodate, Sapporo & Asahikawa & 360 & Partly in full operation; \\
& & & & & & partly under construction; \\
& & & & Partly only listed in Based Plans \\
& Hokuriku & Tokyo & Kanazawa & Osaka & $491 *$ & Partly in full operation; partly under \\
& & & & Kagoshima & 257 & In full operation \\
& Kyushu-Kagoshima & Fukuoka & Kumamoto & Nagasaki & $90 *$ & Under construction \\
3rd & Kyushu-Nagasaki & Fukuoka & Takeo & Osaka & c.a. 500 & In planning \\
4th & Chuo (Maglev) & Tokyo & Nagoya & N/A & c.a. 3000 & Only with Base Plans \\
& Other 10 routes & N/A & N/A & - & c.a. 7000 & -
\end{tabular}

*Overlapping parts with other lines are excluded 
- National Highways: Roads making the nationwide trunk road network together with the expressways;

- Prefectural Roads: Roads making the regional trunk road network;

- Municipal Roads: Road within municipality.

The other ones that do not fall under the Road Act 1952 are private roads, forest roads, agricultural roads, port roads, park roads, touristic roads under Road Transportation Act 1951 (Douro-Unso-hou 1951), and pathways such as trekking routes [4]. All of these are designated for local transport and thus this paper does not deal with them.

\subsubsection{National Highways (Kokudo, conventional roads)}

National Highways (Kokudo) in Japan is the conventional type of intercity roads. Already in the 1870 s, the historical nationwide road network that had been established by the previous feudal era was designated as National Highways by a governmental directive. Several major revisions were made before the end of World War II, such as when the first Road Act 1896 went into force, a major revision in 1919 as well as some other minor revisions of the network [6, 28].

In the post-war period, the new Road Act 1952 went into force and the National Highways are to be designated by the Minister of Construction (today by the MLIT-Minister). As the focus of the nationwide network shifted gradually to the expressways, there is neither a master plan nor other plans of this kind at the time of research [5].

A separate Act on Emergency Measures for Road Developments (Douro Kinkyu-Seibi Sochi-hou) came into force in 1958. This act mainly aims to give a financial framework for the new construction and upgrading of roads. ${ }^{3}$ Pursuant to this Act, Road Development Five-year Plans were made and came into force. These five-year plans indicated policy goals of road development and the investment amounts for road construction projects. This act also established a framework to finance such rapid construction of the road. In 2003, it was merged into the Priority Plan for Infrastructure Development (Shakai-Shihon Seibi Juten-Keikaku) together with other types of civil infrastructures. The most recent plan was published in 2015 [5, 6].

The development, extension and upgrade of the roads was largely funded from the so-called Road Designated Financing (Douro Seibi Tokubetsu Kaikei), which was initiated in 1958, extended step-by-step, and discontinued in 2009. The major source of this budget was the taxation on fuel and vehicle ownership. In the earlier years, this was solely used for the road, while in the later years, the budget was also used for

\footnotetext{
${ }^{3}$ Similar frameworks are used for different infrastructural investments such as fishery port, coastal management, housing, sewage, urban parks, measures against landslides, etc.
}

various types of measures related to urban road traffic, such as the construction of the underground or viaduct railways to eliminate level crossings, as well as tramways and underground parking [5].

\subsubsection{Expressways}

The concept of Expressways first appeared in a government document in 1943 during World War II, when the Ministry of Internal Affairs, which was responsible for the road then, published the National Automobile Highway Plan (Zenkoku Jidousha Kokudo Keikaku) of 5490 km, which is believed to be much influenced by the concept of German Autobahns [28]. Some feasibility studies were carried out, but the plan was abandoned in the next year $[5,6]$.

The planning in the post-war period was brought into a legislative scheme under the Act on Construction of Trunk Expressway for National Land Development 1957 (Kokudo Kansen Jidosha-do Kensetsu-hou). This act's aims are defined as follows:

This act aims to open high-speed trunk expressways throughout the country and to promote the constructions of new urban and agricultural areas. A new nationwide high-speed road network enables universal development of the country, promotes innovative industries, extends the life field of the citizens, and is an inevitable basis for the industrial development. (Article 1, Act on Construction of Trunk Expressway for National Land Development (Kokudo Kansen Jidosha-do Kensetsuhou), translated by the author.)

As such, the expressways in Japan were planned as a tool of industrial developments from the beginning. The entire legislative structure related to the expressway today is fairly complicated: the main point is that there are four categories of expressways nowadays as listed below [5]:

- Expressways (“A-Routes”);

- National Highway parallel to planned Expressways (“A'Routes");

- High-standard National Highway ("B-Routes");

- Roads connecting Honshu and Shikoku;

The concept of these four types appeared in the fourth Zenso in 1987 for the first time (See Table 1). These four groupings serve as a blueprint for the nationwide expressways of approximately $14,000 \mathrm{~km}$. However, each of them are based on different masterplans as summarized below [5].

The A-Routes consists of those designated by the Expressway Act 1957 (Kousoku-Jidosha-Kokudo hou) and the Expressway Routing Directive 1957 (Kousoku-Jidosha- 


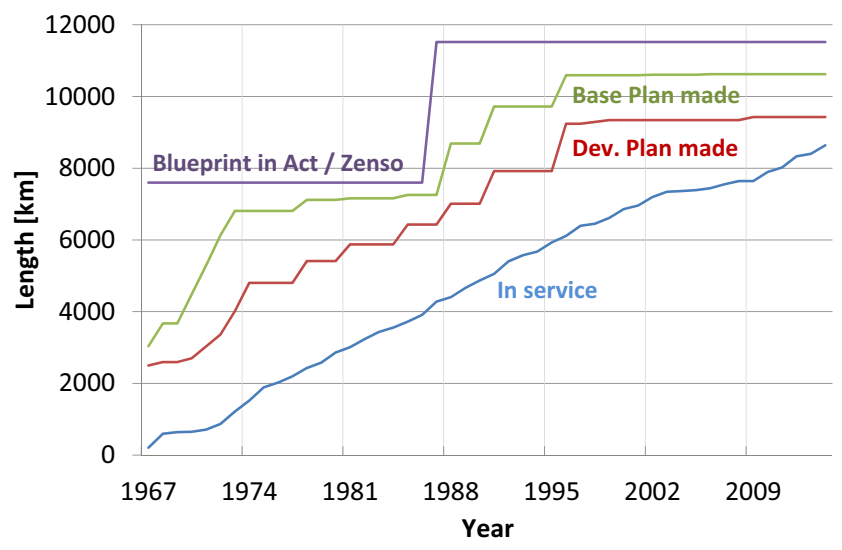

Fig. 2 Length of expressways in blue print, basic plan, construction plan and in service (Source: [5])

Kokudo-no Rosen-o Shitei-suru Seirei), together with several special routes such as ones connecting airports to existing expressways. First, in 1957, approximately $7600 \mathrm{~km}$ of the routes were planned. It was gradually extended and the fourth Zenso defined $11,520 \mathrm{~km}$ of the network (see Fig. 2). This plan is still legally binding at the time of writing this paper. Similar to the case of the high-speed railway, Base Plans for each of the lines are made based on this blue print, and then more detailed Development Plans are made. As of 2014, Base Plans for 10,623 km have been made, and $9428 \mathrm{~km}$ out of them already have Development Plans. Among them, $8638 \mathrm{~km}$ are in service in 2014 [5].

In principle, the construction and the maintenance of the ARoute expressways are first budgeted with designated debts and support from the national budget, and then the income from the toll is used for the redemption. Thus, at large, the expressways' financing is separate from the aforementioned Road Development Designated Budget. In recent cases of rural A-Route expressways from which enough toll revenue is not expected to cover the maintenance cost, $75 \%$ of the construction cost and all of the maintenance cost are financed directly by the state. ${ }^{4}$ At the time of the research, about $8.8 \%$ $(834 \mathrm{~km})$ of the A-Route expressways in service or with Development Plans is financed under this scheme. This new financial scheme was introduced in 2003 in line with the "privatization" of the public expressway enterprise (Japan Highway Public Corporation) into three government-owned joint-stock companies (collectively known as NEXCOs) and Japan Expressway Holding and Debt Repayment Agency, ${ }^{5}$

\footnotetext{
${ }^{4}$ The rest of the $25 \%$ of the construction cost is funded by the prefectural government in this scheme. Of note, it is reported that this financial cost of the prefectural government is compensated by several different means, such as increase of the tax income transfer from Vehicle Weight Tax from the national government to the prefectural governments.

5 This is different from what is commonly called "privatization" in English; however, the term is used here for the sake of coherence with what is called "privatization" in Japan in this particular case.
}

which took place in 2005. However, it is worth highlighting that this reform focused on financial frameworks, and did not fundamentally change how the expressway in the country is planned [5].

The B-Routes are constructed as National Highways and specifically designated as Expressways - this means that the road is built in line with a technical standard of the expressway (curve, gradient, interchanges, etc.) and as a vehicle-only road. The major difference between the $\mathrm{A}$ and $\mathrm{B}$ routes are the administrative process and their financing schemes. Administratively, the A-Routes are listed in the Act on Construction of Trunk Expressway for National Land Development, while the B-Routes are only designated by the minister, and the authorization of the Base and Development plans are at a different level. ${ }^{6}$ Financially, the A-Route's construction costs are basically covered by the income mainly from the toll and the support from the government's budget, while the B-Routes' construction costs are covered fully by the government's and prefectures' budget. $2480 \mathrm{~km}$ are planned in the fourth Zenso.

An exception is the A'-Routes: this is constructed as a part of the National Highway network, with a perspective to be integrated into the expressway network later. This is mostly used to construct new tunnels or bypassing routes near large cities.

The decision to be made for the Base Plan and the Development Plan are as shown in Table 4. The length of expressways in the blueprint set by the 4th Zenso, the Base plan, the Development Plan and $\mathrm{km}$ in service are summarized in Fig. 2.

\subsubsection{Seaports}

The waterway, both inland and on the sea, was the most important freight transport mode before the appearance of the railway in Japan. Shipbuilding has seen its own development and Japanese ships were widely used (Benzai-sen, also known as Sengoku-bune) until the Edo and early Meiji Periods for domestic freight transport. Since the seventeenth century, along with the development of the market economy, offshore waterways and seaports along the coast were gradually developed. The western routes (so-called Kitamae-bune, connecting Osaka and Hokuriku to Hokkaido via the Seto Inland Sea and Kanmon Straits), which was run by shipowner-merchants, saw a particular prosperity (See e.g. [12]). After industrialization in the late nineteenth century, the railway and later the truck overtook the role as the main mode for longdistance freight transport. However, around $40 \%$ to $45 \%$ of the goods within Japan are still transported by ship (based on

\footnotetext{
${ }^{6}$ The Base and Development Plans for the A-Routes are authorized by the minister, while those for the B-Routes are authorized by the chief officer of the road department of MLIT.
} 
Table 4 Overview of the contents of the base and development plans of A-Route and B-Route expressways, Source: [29]

\begin{tabular}{|c|c|c|}
\hline Type of plan & A-routes & B-Routes \\
\hline \multirow[t]{4}{*}{ Base Plan } & $\begin{array}{l}\text { Origin and end of the route; } \\
\text { Intermediate points en route; }\end{array}$ & Name of the route; \\
\hline & $\begin{array}{l}\text { Basic technical design } \\
\quad \text { (number of lanes, speed); }\end{array}$ & $\begin{array}{l}\text { Origin, end and approximate } \\
\text { length en route; }\end{array}$ \\
\hline & Locations of interchanges; & Major intermediate points; \\
\hline & Implementation body & Technical standard (lanes, speed) \\
\hline \multirow[t]{6}{*}{ Development plan } & Municipalities along the route; & Name of the route; \\
\hline & $\begin{array}{l}\text { Technical design in detail } \\
\text { (number of lanes, speed); }\end{array}$ & Origin, end and approximate length; \\
\hline & Locations of interchanges; & Municipalities en route; \\
\hline & Approximate envisaged construction costs; & $\begin{array}{l}\text { Technical design in detail } \\
\text { (lanes, speed, width, etc.); }\end{array}$ \\
\hline & \multirow[t]{2}{*}{ Other minor points to be pointed out. } & Locations of interchanges; \\
\hline & & $\begin{array}{l}\text { Approximate envisaged } \\
\text { construction costs. }\end{array}$ \\
\hline
\end{tabular}

ton-km). In the last decades, as Japan increased its imports and exports and along with the globalization of the economy, the role of international bulk, Ro-Ro and container transport is becoming more important.

It is worth noting that there is a clear distinction between transport seaports and fishery seaports in Japan today. These two are planned, developed and managed separately under separate legislative frameworks, and thus they are not to be confused. In this section, the transport seaports are dealt with. ${ }^{7}$

Nowadays, Japan's ports are categorized into the following five groups. Almost all of them are on the sea, with a few exceptional regional ports on rivers and lakes, and are managed by prefectures or municipalities.

- International Strategic Ports: International container-hub ports ( 5 ports)

- International Gateway Ports: Ports serving as international gateways both for bulk and container transport (18 ports)

- Important Ports: Ports serving mainly domestic sea routs (102 ports)

- Regional Ports: Other ports mainly serving regional uses, such as ferries connecting small islands with the mainland (808 ports). Among them, 35 ports are designated as Emergency Ports, which serve as a shelter in case of natural disaster (e.g. tsunami, typhoon).

- So-called Article-56 Ports: Exceptional ports without land-side areas designated by prefectures' governors. Either a very small port or a seaside area to be developed as a port in the future.

\footnotetext{
${ }^{7}$ In some exceptional case, a part of a transport port may also serve as a fishery port. It is possible that a transport port and a fishery port are located next to each other within the same municipality. There are a few transport ports located on rivers or lakes, but they are small and do not play a significant role within the national transport network.
}

As is the case with transport infrastructure other than railways, Port Development 5-year Plans (Kouwan Seibi Gokanen Keikaku) was regularly made, and functioned as an indication of the financial investments required to upgrade, expand or newly construct transportation ports. This was discontinued in 2003 and integrated into the aforementioned Priority Plan for Infrastructure Development.

The Port Act (Kouwan hou) stipulates the Basic Policy and Objectives for Developments, Utilization and Maintenance of Ports and Key Sea Lanes to be prepared and approved by the MLIT. The latest version published in 2011 indicates the following points [30]. Similarly to the case of the latest National Land Formation Plans, it is written rather in an abstract manner:

1. Logistics chain for international industrial competitiveness and supporting citizens' lives;

2. Contribution to the safety of the citizens;

3. Creating favorable port environments;

4. Creation of vivid and beautiful port space and appropriate management;

5. Promotion of" new ocean policy" for a" new ocean nation";

6. Efficient and effective undertaking of projects in response to stock-rich society.

Pursuant to the Port Act, a Port Plan (Kouwan-Keikaku) is made by each port authority (prefecture or municipalities). This is a long-term strategic plan focusing on each single port, and it indicates the implementation of infrastructure, spatial planning, and environment protection.

\subsubsection{Airports}

Civil aviation in Japan was mainly developed in the post-war period, as is the case in many other developed countries. 
During the period of occupation between 1945 and 1952, matters related to aviation were under the control of the Allies [7, 8, 31].

In 1956, the Airport Development Act (Kuuko-Seibi hou) came into force and this is the basis for airport planning today. This aimed solely at the construction and extension of airports. It was reorganized in 2008 and became the Airport Act, which aims to "improve the benefits of airport users in harmonization with the environment by defining the rules for the effective and efficient placement and management of the airport, as well as to strengthen a industry and tourism and to contribute to vitalizing regional economies". In this new Act, a clear distinction is made between "airport" serving scheduled passenger flights and other ones as "aerodrome" serving private aircrafts only for the first time [7].

Under the Airport Development Act 1956, airports were categorized into the following three categories, and this classification stipulates the managing body and the basic financial framework for the key facilities for air traffic (e.g. runways and taxiways, air traffic control system, etc.):

- Category I: international airport serving the major international civil aviation network; managed by the state or designated airport companies; fully funded by the state;

- Category II: airport serving the trunk civil air routes within Japan, managed by the state; $2 / 3$ funded by the state and $1 /$ 3 funded by the prefecture and/or municipality in which it is located;

- Category III: airport serving regional air traffic; managed by prefecture or municipality; $1 / 2$ funded by the state and rest funded by the prefecture and/or municipality in which it is located.

- Hub Airports: airports serving as network hubs, subcategorized into the following three;

- Airports managed by the state (19 airports); $2 / 3$ funded by the state and $1 / 3$ funded by the prefecture and/or municipality in which it is located, with the exception of TokyoHaneda which is fully funded by the state;

- Airports managed by designated airport companies (4 airports: Tokyo-Narita, Osaka-Kansai, Osaka-Itami, Nagoya-Chubu); Funding organized by respective airport companies;

- Airports managed by regional governments (5 airports); $55 \%$ funded by the state, $45 \%$ funded by the prefecture in which it is located;

- Regional airports: airports serving regional air traffic i.e. former Category III airports managed by regional governments ( 54 airports); $1 / 2$ funded by the state and rest funded by the prefecture and/or municipality in which it is located.
- Shared airports: airports managed by Japan Self-Defense Air Force, US Air Force or US Marine Corps also serving civil aviation ( 8 airports); $2 / 3$ funded by the state and $1 / 3$ funded by the prefecture and/or municipality in which it is located;

- Other airports: airports not designated by the Airport Act, serving private aircraft and/or small commuter aircraft; no funding scheme defined in the Airport Act.

As is the case of other transport infrastructure other than the railways, since 1967, Airport Development 5-year Plans (Kuukou-seibi Gokanen keikaku, later it became 7year Plans) were approved every five (later seven) years. This was discontinued in 2003 and integrated into the aforementioned Priority Plan for Infrastructure Development. As is the case of the other transport modes, these Development 5-year Plans indicate the monetary amount of the investment. The short-term objectives are listed (up to 5 years) and these are based on the predicted amount of passengers in air transport, and the plan is made to increase the capacity of the airports to meet such estimated demands. As such, the objectives were set in a demand-driven manner.

For example, the main objectives of the second 5-year plan designated for 1970 to 1975 were (1) continuous construction of (already approved) new airports in Tokyo and Osaka (today's Narita and Kansai Airports); (2) further development of other airports (Tokyo, Osaka, Others); (3) further installation of navigation systems; and (4) promotion of noise-mitigation measures. The planned investments for each airport are listed in the Plan [32].

In the first phase of the airport developments, the (aforementioned) Port Development Designated Fund was used. Since 1970, in parallel to the introduction of the 5-year development plan, an Airport Development Designated Fund was established. This was integrated in 2008 as a part of the Infrastructure Development Designated Fund. This is funded by the airport fee and the air traffic control fee paid by the airlines, the tax on the aircraft fuel, as well as the contribution from the general budget and loans [7].

\subsection{Basic act on transport policy 2013 and basic plan on transport policy}

In December 2013, the Basic Act on Transport Policy (Koutsu Seisaku Kihon-hou) was approved by the Diet and came into force immediately. This new law is expected to fill the gap between the National Land Formation Plan and Infrastructure Development Priority Plan that is liaised with the Infrastructure Development Designated Fund. It constitutes the basic transport policy, and in line with this the MLIT is to publish a Basic Plan on Transport Policy (Koutsu Seisaku Kihon-keikaku) [33, 34]. 
The Act constitutes the five key policy focuses of transport, namely (1) to fulfill the basic needs of the citizens, (2) and transport's roles in society and economy as well as in case of natural disaster, (3) reducing environment impacts, (4) division of roles among various transport modes and collaboration among them (multi-modal transport), and (5) safety.

Pursuant to this Act, the first Basic Plan on Transport Policy was published in 2014. The three pillars of it are [35]:

(a) Usable transport system enabling "socially rich" lives: restructuring the regional transport system in line with urban development, supporting the introduction of various transport services that match the needs of each region (e.g. bike-sharing schemes), (physical) barrier-freeness, and improvement of service level;

(b) Establishing international and interregional passenger and freight transport systems as a basis of growth and prosperity: improvement of international transport network, increasing interregional passenger and freight transport, collaboration with tourism policy to enable 20 million foreign visitors to Japan per year, and exporting transport technologies and services;

(c) Basis for sustainable and safe transport: resiliency for disasters and aging infrastructure, enforcing stable and safe service provision (of transport operators), education of professional human resources, and $\mathrm{CO}_{2}$ and energy reduction.

The Basic Plan set 93 quantitative key performance indicators, most of which are to be achieved by 2020 [36]. Apart from the indicators that are related to safety and infrastructural resiliency, the focus of the indicators are still on the "increase" of passengers or similar, and they are mostly on an operational level (e.g. " $70 \%$ of buses to be barrier-free by 2020 "). Few measurable indicators are set on a strategic level, such as targeted modal shares, or a reduction of $\mathrm{CO}_{2}$, noise, pollutants or traffic accidents by modal shift.

There are some indicators with some characters related to strategy, but these tend to be often incomplete. For example, there are two indicators about a modal shift in freight transport on the list: "ton- $\mathrm{km}$ transported by railway from 18.7 billion ton-km in 2012 to 22.1 billion ton-km in 2020", and "ton-km by domestic sea routes from 33.3 billion ton- $\mathrm{km}$ in 2012 to 36.7 billion ton-km in 2020". However, no performance indicators regarding the freight transported on the road is set - thus these indicators cannot be used for evaluation of a freight modal shift because increased ton-km carried by rail and sea may just be a result of the total increase of the freight throughout the country. As such, there are several basic shortcomings in that the indicators are often operational rather than strategic, and some indicators are incomplete.

The three pillars as well as the detailed description in detail is much about policy measures that have already been implemented or that are to be started, as stated in its foreword. It does not have a character to be called masterplan or alike, which determines comprehensive or strategic development of the transport system of the country.

\section{Comparison of national-level planning schemes for different transport modes}

\subsection{Overarching plans}

As seen in the earlier section, the Zensos and its successor the National Land Formation Plan (Kokudo-Keisei-Keikaku, NLFP) indicate general concepts of spatial development. However, this is often written in a conceptual manner, and merely points out the key focus or goal-setting for the next decade. Initially, the Zenso were intended to be an economic development plan with transport policy as one part of it, and later it was expanded to wider aspects related to spatial development at the national level. In short, the Zensos are not meant to serve as the national transport master plan.

The new Base Plan on Transport Policy was published in 2013 for the first time. In it, modal shifts and some other measures related to intermodal transport are, to some extent, manifested; however, the goals set in the plan as well as the measurable indicators in it are mostly for single modes. It is still far from what is internationally called strategic or comprehensive planning, or from a design of the national transport system with different modes of transport well integrated.

As such, there is substantially no national-level planning scheme dealing with or aiming to integrate different transport modes in Japan as of yet. Strong independence among each of the transport modes is still observed, while few plans make efforts to coordinate these different transport modes. This situation in turn brings about a lack of a strategy for the national transport system. Policymaking for intermodal and multimodal transport is also substantially lacking.

\subsection{Comparison among planning schemes for different modes}

For each of the long-distance transport modes, the planning and construction processes of single lines or ports are precisely stipulated and enforced as seen in the previous section. High-speed railways and expressways have their legally binding blueprints, while Base Plans and Development Plans are rooted within their robust legislative frameworks. It is worth highlighting that the blueprints have not been revised since the 1970s in the case of high-speed railways, and since the late 1980s in the case of the expressways. The conventional railways, national highways, transport ports and civil airports 
Table 5 Summary of national-level planning frameworks for each type of transport infrastructures

\begin{tabular}{|c|c|c|c|c|c|c|}
\hline $\begin{array}{l}\text { Type of } \\
\text { infrastructure }\end{array}$ & $\begin{array}{l}\text { Act stipulating } \\
\text { developments }\end{array}$ & $\begin{array}{l}\text { Designated funding } \\
\text { scheme }\end{array}$ & $\begin{array}{l}\text { 5/7-year Implementation/ } \\
\text { Development plan* }\end{array}$ & Blueprint & $\begin{array}{l}\text { Base } \\
\text { plan }\end{array}$ & $\begin{array}{l}\text { Development } \\
\text { plan }\end{array}$ \\
\hline $\begin{array}{l}\text { Conventional } \\
\text { railway }\end{array}$ & - & - & $\begin{array}{l}\text { Since } 2003 \text {, only as a } \\
\text { small part of integrated } \\
\text { plan }\end{array}$ & (Until 1987) & - & - \\
\hline $\begin{array}{l}\text { High-speed } \\
\text { railway }\end{array}$ & $\begin{array}{l}\text { Shinkansen } \\
\text { Development Act }\end{array}$ & $\begin{array}{l}\text { MoU btwn. Govt. \& } \\
\text { ruling parties }\end{array}$ & - & (Base Plan) & $\checkmark$ & $\checkmark$ \\
\hline National highway & Road Act & $\begin{array}{l}\text { (Until 2013, then } \\
\text { transferred }\end{array}$ & $\checkmark$ & $\begin{array}{l}\text { (Cumulating } \\
\text { Designation) }\end{array}$ & - & - \\
\hline Expressway & $\begin{array}{l}\text { National Trunk } \\
\text { Expressway } \\
\text { Construction Act }\end{array}$ & to general budget) & $\checkmark$ & $\checkmark$ & $\checkmark$ & $\checkmark$ \\
\hline Seaport & Port Act & & $\checkmark$ & - & - & - \\
\hline Airport & Airport Act & & $\checkmark$ & - & - & - \\
\hline
\end{tabular}

*These were separately made for roads, seaports and airports until 2003, and then merged into one with other civil infrastructures

have no such blueprint comparable to the high-speed railway and expressway. This is summarized in Table 5. This table also indicates any act stipulating developments of each types of infrastructure, if there is any designated financing scheme at the national level, and if there used to be five-year or sevenyear implementation plans.

\subsection{Legislative and structural imbalance between rail and road}

As for the two land-based modes, namely railways and roads, at first sight, the planning schemes may look similar and well balanced, as there are concrete long-term development schemes for both the high-speed railway and the expressways. It is also similar in that no such long-term blueprint, base plan and development plan exist at the national level for conventional railways or national highways.

However, at a closer look, the concrete long-term development plan (Base Plan) for the high-speed railway has been made only for the main transport corridors of c.a. $4000 \mathrm{~km}$, while about $17,100 \mathrm{~km}$ of the conventional railway is in operation without any master plan or blueprint for the future. The corresponding Development Plan for the expressway has been already made for about $9500 \mathrm{~km}$, and in total approximately $14,000 \mathrm{~km}$ of expressways are in operation or planned (See Fig. 2). Eventually the expressway network will cover much wider areas of the country compared to the high-speed railway and are more comparable to the conventional railway. The planning and infrastructural situations for each of the land-based long-distance modes are summarized in Table 6.

It is easy to observe that the conventional railway is comparable to the expressway in terms of network length. Moreover, it is worth highlighting that the door-to-door travel speed with the conventional railway and the expressway tend to be comparable, while that of the high-speed railway is more comparable with air transport. At large, these lead to a situation that the expressways are becoming a counterpart to and eventually a main competitor of the conventional railway.

When comparing these two competing transport modes in Japan today, there is a clear imbalance in terms of the planning systems that exist. The conventional railway has no blueprint that is legally binding, and there is neither a base nor development plan at the national level. On the contrary, the expressway has extensive Base Plans and Development Plans stipulated by the designated legislative framework for the A-Routes, and on top of that, there is a similar framework for the B-Routes. In short, the expressways have a more robust long-term planning scheme compared to that of conventional railways.

Table 6 Comparison of legally-binding network length, planned length and length in service

\begin{tabular}{lllll}
\hline Type of infrastructure & $\begin{array}{l}\text { Blueprint in length }[\mathrm{km}] \\
\text { and legislation for it }\end{array}$ & Length with Base Plan [km] & $\begin{array}{l}\text { Length with Development } \\
\text { Plan [km] }\end{array}$ & Length in Service [km] \\
\hline Conventional railway & None & N/A & N/A & 17,135 \\
High-speed railway & (Identical to Base Plan) & C.a. $7000 \mathrm{~km}$ & C.a. $3956 \mathrm{~km}$ & 2765 \\
National highway & None & N/A & N/A & 54,736 \\
Expressway A-Routes & $11,520 \mathrm{~km}$, a designated act & $10,623 \mathrm{~km}$ & $9428 \mathrm{~km}$ & 8402 (March 2014) \\
\multicolumn{1}{c}{ B-Routes } & $2480 \mathrm{~km}, 4$ th Zenso & unknown & $2045 \mathrm{~km}$ (March 2008) & $1458 \mathrm{~km}$ (March 2013) \\
\hline
\end{tabular}


Such different levels of planning scheme robustness can be demonstrated and tested in the case of a severe natural disaster, when acute planning for reconstruction is called for. In the next section, with an example of the recent catastrophic disaster caused by the earthquake and the tsunami in 2011, this difference is discussed.

\section{Severe natural disasters and their impacts on transport infrastructures}

\subsection{Overview of major disasters in Japan that largely affected transport infrastructures}

The transport infrastructure has been repeatedly damaged from various natural disasters in the country. Because road and rail infrastructures constitute the ground transport networks, which can directly be affected by localized damage, the damages to road and rail infrastructure tend to be more critical than those to port and airport infrastructure. Such "pinpoint" types of damage to the rail and road transport infrastructure affects wider parts of the network. On the contrary, damages to the airport and seaports tend to be more limited in manner because this infrastructure stretches only locally and the transport networks are oriented around airborne or seaborne services.

Although damages to infrastructure can be mitigated through various measures, by their nature, natural disasters are not plannable: it is the natural disaster itself that triggers acute planning and reconstruction. Under such circumstances, preparedness and robustness of the long-term masterplans, which are made differently for each transport mode as seen above, are tested. Moreover, a comparison between the two ground transport modes - road and railway - can demonstrate different levels of preparedness and robustness embedded in the Japanese planning schemes of the two ground transport modes.

Of note, in case of small natural disasters, damages are immediately repaired where possible, and the original services are recovered within a few months at longest. However, in the case of less frequent but catastrophic natural disasters, rural railways face a major risk of being closed while roads do not. It is such severe natural disasters that demonstrates the different levels of preparedness and robustness of the long-term planning schemes.

In the following sections, first impacts from the 2011 earthquake on the transport infrastructure as well as its reconstruction plans are briefly summarized to demonstrate the different levels of robustness in long-term planning for road and railway infrastructure. Afterwards, natural disasters and their impacts on transport infrastructure since the 1990s are briefly reviewed: this is the time when much of rural railways have faced to a risk of closure as a consequence of severe natural disasters. Through this process, it is easy to observe that some rural railways are affected by severe natural disaster, which leads to a risk of closure.

\subsection{Tohoku earthquakes and its consequences to mid-} to long-term reconstruction planning

\subsubsection{Overview}

The M9.0 earthquake in March 2011, often referred to as the Great East Japan Earthquake, with the following tsunamis and meltdown of the Fukushima nuclear reactors caused the most severe consequences to the transport infrastructure in the country's modern history.

In the most severely damaged area (roughly corresponding to Fukushima, Miyagi and Iwate Prefectures, approximately $500 \mathrm{~km}$ ), the land-based transport corridor, along with the cities and settlements along it, is characterized by the massive destruction by the disaster. Figure 3 is a schematic diagram summarizing the afterdisaster situation of the conventional railway and the expressways along this corridor. Of note, there is no highspeed railway planned or in operation along this corridor and, there are national highways parallel to the expressway.

\subsubsection{Expressways and other road infrastructure}

Many of the existing main roads (expressways, national highways and prefectural roads) were cleared, and then repaired immediately after the earthquake-tsunami damage, with a few exceptions that were damaged by severe landslides caused by the quake or the fall of bridges caused by the tsunami. The expressways were not severely damaged as they are mostly built at least a few kilometers inland in order to avoid the center of existing cities and settlements. Where they do exist, all of the expressways were made open to emergency vehicles within a few days, and to general traffic within a few weeks.

This enabled emergency logistics soon after the disaster that was mainly undertaken by automobiles and military vehicles. Within a few months, severely broken bridges were replaced with temporary ones, and the landslide blocking the road was cleared. It is worth noting that the road can be repaired much faster compared to the other types of infrastructure because of its technical characteristics, and it can serve emergency vehicles as well as general traffic: thus this rapid repair of the existing road is to be expected.

Moreover, as seen in Fig. 3, many of the expressway sections that did not exist before were added after the 2011 catastrophe. In particular, all of the missing parts at the time of the catastrophe (pink parts in Fig. 3) were initiated as construction projects by November 2011 (only 10 months after 

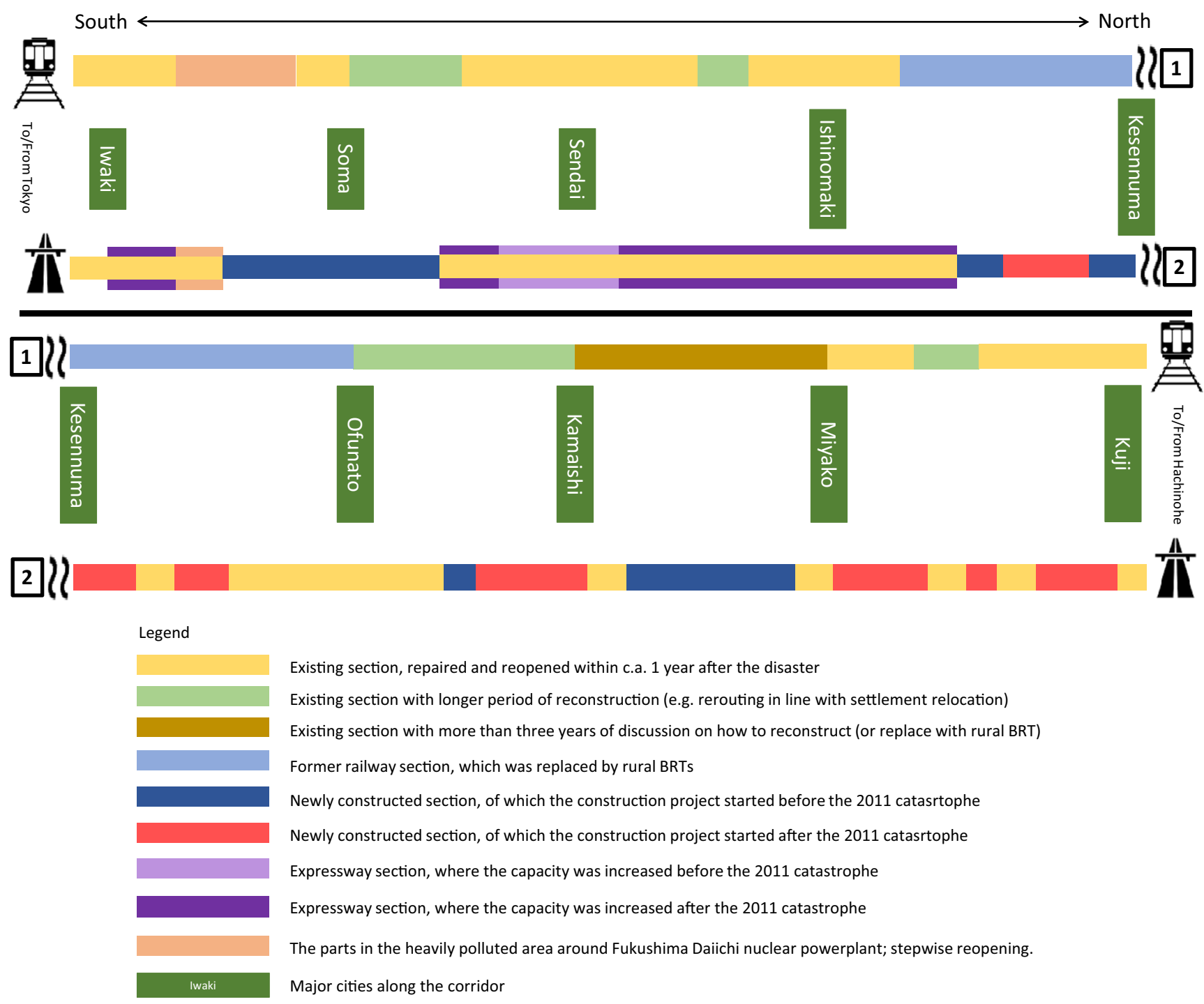

Fig. 3 Schematic comparison of the reconstruction situations between conventional railway and expressway after the 2011 catastrophe (Source: own diagram)

the earthquake), and the expressway route along the corridor will be completed within a decade or so. All of these were envisaged in the 4th Zenso in 1987, and planned as A-Routes (south from Sendai) or B-Routes (north from Sendai, "Sanriku coastal expressway" in Table 7). Other expressways, which were also envisaged in the 1987 Zenso, are being constructed from the inland to the coast since the 2011 catastrophe, as summarized in Table 7.

As such, the construction of the expressways was clearly fueled by the catastrophe, with help form the existing longterm plans. Of course, this is not to say that these expressways would not have been constructed without the disaster. It

Table 7 "Reconstruction supporting expressways" as of March 2015, Source: MLIT

\begin{tabular}{llllll}
\hline Name of expressway & Direction & Total length $[\mathrm{km}]$ & In operation $[\mathrm{km}]$ & Under construction $[\mathrm{km}]$ & $\begin{array}{l}\text { Section approved in 2011 } \\
\text { or later [km] }\end{array}$ \\
\hline Sanriku coastal & Coastal & 359 & 152 & 207 & 148 \\
Miyako-Morioka & Inland to coast & 100 & 8 & 58 & 48 \\
Kamaishi-Hanamaki & Inland to coast & 80 & 54 & 26 & 17 \\
Tohoku central & Inland to coast & 45 & 0 & 45 & 23 \\
Total & N/A & 584 & 214 & 336 & 236 \\
\hline
\end{tabular}




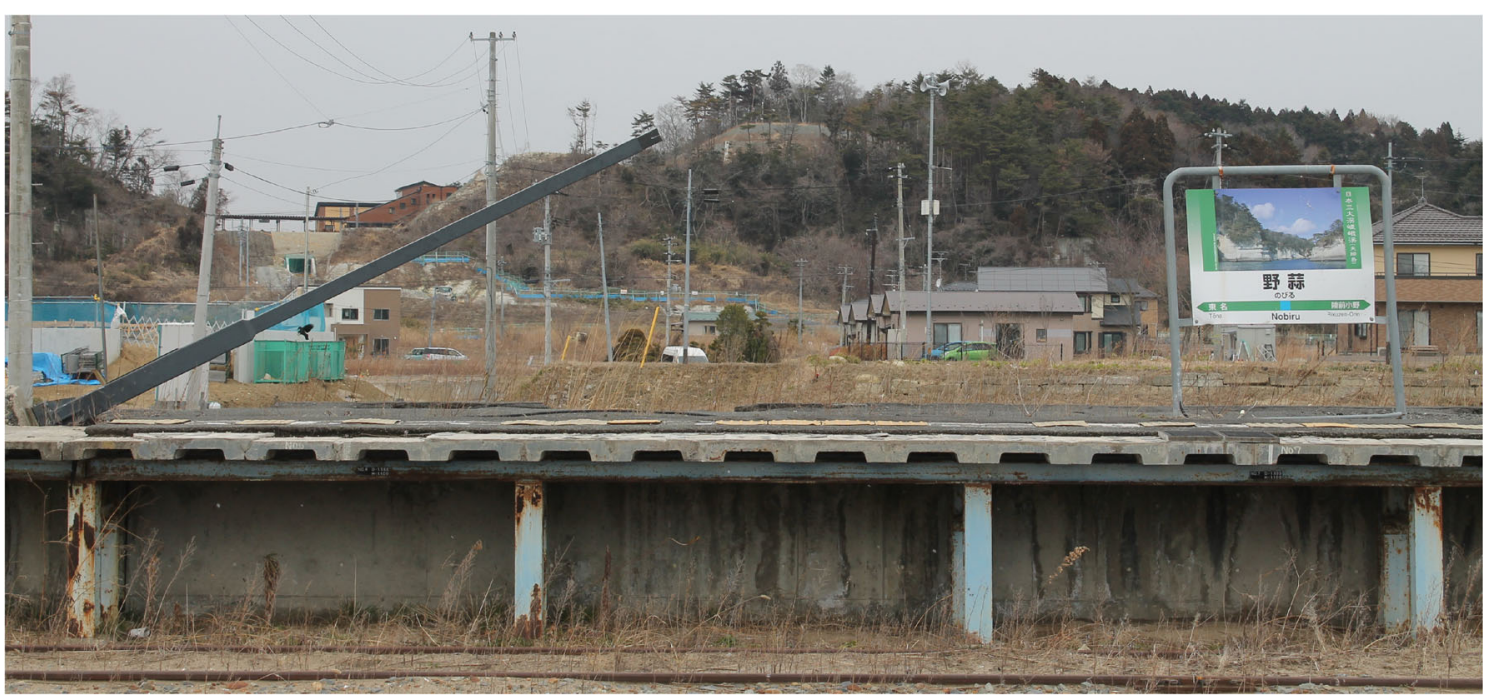

Fig. 4 Abandoned tsunami-damaged railway station and the settlement surrounding it (front), and newly-built station on the hill where the entire settlement was relocated (Source: own photograph taken in March 2014)

should be understood that the natural disaster accelerated the completion of previously Zenso-envisaged expressways in the region.

\subsubsection{Railway}

The earthquake and/or the tsunami caused severe damage to many of the railway lines in the region. Easy-to-repair damages such as tilting overhead wire poles or marginal position aberrations of bridges or viaduct girders were repaired quickly, and service was back at the original level within a year, often within a few months. As many of the railway lines serve the centers of cities and settlements in the region, which are close to the coastline and were severely destroyed by the tsunami, the damage to the railway infrastructure tended to be severe compared to that of the expressways.

In the southern parts from the Ishinomaki area (about $50 \mathrm{~km}$ north of Sendai), where the population density is relatively high, railway lines have been fully reconstructed and put into full operation, with the exception of the radioactively polluted area in Fukushima, which will be completed by 2020 . Some parts of the line were relocated in line with the resettlement of some severely damaged coastal settlement (see Fig. 4).

The situation regarding the railways north of the Ishinomaki area, where the population density is not only much lower but also rapidly aging and decreasing, looks somewhat like a patchwork. It consists of (1) the part with limited damages that was quickly repaired within approximately one year, (2) the part replaced by the rural BRT instead of being reconstructed, (3) the severely damaged part with more than three years to decide whether to reconstruct or not, and (4) the part that, despite heavy damages, was fully reconstructed either in the same place or along with the settlement relocation.

In the case of (4), the state partly aided with the settlement relocation, or fully aided using a general framework of public financial aid to recover from natural disasters applied to deficit-making railway undertakings. The parts (2) and (3) had a similar level of damage as (4), but no such state aid for reconstruction was made; in this case, the railway undertaking in charge of these parts did not fulfil the eligibility criteria for the financial aid for the recovery. ${ }^{8}$

As such, the differentiation among (2), (3), and (4) is mainly based on the cost burden. As there is no long-term blueprint for railways comparable to that of the expressway, the discussion and negotiations among various stakeholders (the state, prefectures, municipalities, and railway undertakings, as well as railway infrastructure owners if any) cannot be based on any long-term network planning as a corollary. Such costbased issues in these types of shrinking regions would have arisen sooner or later without a severe natural disaster as the service provision and the maintenance of the railway incurs certain costs: it should be understood that the natural disaster accelerated the emergence of the cost issue on the agenda, together with the question of the large reconstruction cost.

\footnotetext{
${ }^{8}$ The act stipulating railway reconstruction from natural disaster has a socalled "deficit contingency." In case an operator as a company faces a series of operational deficits in three years prior to a disaster, the state and prefecture (or municipality) aid 50\% of the reconstruction costs. A new rule is set so that the reconstruction of the publicly-owned rail infrastructure is fully publicly financed. However, if an infrastructure owner as a company generates profits in the last years, the state aid is not provided. As the railway undertaking in charge of (2) and (3) do not make such deficits in the previous years thanks to income generated from Tokyo and Shinkansen, no state or prefectural aid was provided.
} 
Furthermore, the process is characterized by a longer period of decision-making by the stakeholders.

\subsection{Is this situation new? - major natural disasters leading to closure of transport infrastructures since the 1990s}

The type of the situation around the railway damaged by natural disasters is not a new case of the 2011 catastrophe. Since the late 1990s, floods, landslides, earthquakes, tsunamis and avalanches have worked as triggers for the closure of regional railway lines. During this period, the closure of railway lines was made easier in 1999 as the railway operator no longer has to get an approval from the ministry to discontinue passenger services. In the new regulation that went into force in 1999, the operators only have to inform the closure to the ministry just one year before a planned closure date. This fueled the closure of deficit-making regional railway lines in general, even if the socioeconomic importance of the lines were not negligible (see e.g. [34]).

One of the most remarkable disasters in this period is the earthquake hitting the City of Kobe in January 1995: damages to the transport infrastructure such as fallen viaducts were recovered quickly. This is a major disaster hitting a large city; the recovery was relatively quick, and practically there was no one questioning the necessity of the recovery.

The situation around rural railways damaged from natural disasters are different. It is common that a "close-or-reconstruct" question arises, and some of them were decided to be closed. Such natural disasters between 1995 and 2015 except for the 2011 earthquake and tsunami are summarized in Table 8. All of them are/were railways running through regions away from main transport corridors. The number of passengers are/were fairly limited at the time of the natural disasters, and they are/were hardly used for freight transport. Of note, other railway lines were also closed in this period without severe damages from natural disasters - in many cases, the main reason for the closure was the operational deficit of the line.

As such, the overall trends regarding the post-disaster situation for rural rail infrastructures are not different from the case of the 2011 catastrophe at least since the 1990s. Natural disasters have triggered "close-or-reconstruct" questions, and sometimes eventually helped accelerate discussions towards closures. At large, the situation has been indifferent since the 1990s in that a closure-orreconstruct question arises regarding rural railways when they are hit by natural disasters. With no help from network blueprint or masterplan, sometimes the railway is eventually closed.

On the contrary, there is no comparable closure of the trunk roads triggered by natural disasters observed in the same period, yet no acceleration similar to the "reconstruction support roads" has been observed either. Such acceleration of the construction of the Zenso-envisaged expressways is probably a new kind of fueling the expressway construction that appeared in the case of the 2011 catastrophe.

\section{Conclusion}

In this paper, after a short literature review in Section 2, a brief overview of the development of Japan in the industrialized era

Table 8 Natural disasters leading to severe damages to railways with "close-or-reconstruct" discussions since 1990s (as of Summer 2016)

\begin{tabular}{|c|c|c|c|c|c|}
\hline Year & $\begin{array}{l}\text { Railway } \\
\text { company }\end{array}$ & Line & Type of natural disaster & Long-term suspension & Consequence as of summer 2016 \\
\hline 1995 & JR West & Oito Line & Flood & 1995-1997 & Reopened in 1997 \\
\hline 2005 & $\begin{array}{l}\text { Takachiho } \\
\text { Railway }\end{array}$ & Takachiho Line & $\begin{array}{l}\text { Typhoon } \\
\text { (flood, bridges lost) }\end{array}$ & Until official closure & $\begin{array}{l}\text { No reconstruction, } \\
\text { officially closed in } 2008\end{array}$ \\
\hline $\begin{array}{l}2006, \\
2013\end{array}$ & JR West & Sanko Line & Flood & $\begin{array}{l}\text { 2006-2007 (1 year) } \\
\text { 2013-2014 (1 year) }\end{array}$ & $\begin{array}{l}\text { Reopened in } 2007 \text { and } 2014 \\
\text { respectively, but planned } \\
\text { closure in } 2018\end{array}$ \\
\hline 2009 & JR Central & Meisho Line & Typhoon (landslide) & 2009-2016 & Reopened in 2016 \\
\hline 2010 & JR East & Iwaizumi Line & Landslide & Until official closure & $\begin{array}{l}\text { No reconstruction, officially } \\
\text { closed in } 2014\end{array}$ \\
\hline 2011 & JR East & Tadami Line & $\begin{array}{l}\text { Heavy rain } \\
\text { (flood, bridges lost) }\end{array}$ & Suspended until today & $\begin{array}{l}\text { Decision not yet made at the time of this } \\
\text { research }\end{array}$ \\
\hline 2012 & JR Hokkaido & $\begin{array}{l}\text { Rumoi Main } \\
\text { Line }\end{array}$ & Avalanches & $\begin{array}{l}\text { Repeated precautionary } \\
\text { closures in every } \\
\text { winter } \\
\text { since then }\end{array}$ & $\begin{array}{l}\text { Once recovered, but closure } \\
\text { planned in late } 2016\end{array}$ \\
\hline 2013 & $\begin{array}{l}\text { Shigaraki } \\
\text { Railway }\end{array}$ & Shigaraki line & $\begin{array}{l}\text { Typhoon (flood and } \\
\text { landslide, } \\
\text { one bridge lost) }\end{array}$ & 2013-2014 & Reopened in 2014 \\
\hline 2015 & JR Hokkaido & $\begin{array}{l}\text { Hidaka Main } \\
\text { Line }\end{array}$ & Surge, Typhoon & Until today & $\begin{array}{l}\text { Decision not yet made at the time of this } \\
\text { research }\end{array}$ \\
\hline
\end{tabular}


is given in Section 3. The planning scheme is reviewed in detail (Section 4) and compared (Section 5). The major impacts from natural disasters to the transport infrastructure focusing on the period since the 1990s are summarized (Section 6).

The key findings and conclusions are as follows. First, for each of the long-distance modes except for the conventional railway, there are comprehensive mid-term and long-term planning schemes and financial frameworks. Some of them, namely high-speed railway and expressway, have robust and comprehensive legislative frameworks with a nationwide blueprint and base plans as well as development plans for each single lines. However, such a blueprint is rarely revised: it seems that only fundamental changes such as the privatization of JNR into JR can lead to such revision. Furthermore, these planning schemes originate from the time of the rapid economic growth - in other words, the scheme aims to fulfill the then rapidly increasing transport demand, or sometimes regional political or socioeconomic wishes.

Second, there has been a clear lack of strong framework to plan intermodal or multimodal transport master plan on a nationwide scale and to implement it, as the aforementioned planning schemes have been much independent to each other. Basic Act on Transport Policy 2013 is evaluated as an important step addressing this; however, the measurable key indicators set within the framework of this act tends to be rather operational and split into each mode as of yet. Further strong comprehension is called for.

Third, natural disasters have had significant impacts especially in the regions further away from the main transport corridors. As demonstrated by the example of the 2011 catastrophe and other examples since the mid-1990s, there is an imbalance between the expressways and the railways. The expressways are helped by the legal framework with the blueprint and associated robust planning processes: the natural disaster seems to have fueled the extension of the expressway in the tsunami-affected area thanks to this robust scheme. The decision to fill the missing links along the corridor was made fairly quickly after the disaster. On the contrary, without a clear blueprint comparable to that of the expressway, the railway seems to have two different situations. One is the area with a denser population and greater intensity of industry: here, decision-making was clear and reconstruction was carried out relatively rapidly. However, in the rural area where the population density is lower, decision-making took much longer, and some sections were eventually not reconstructed and replaced with bus-based transport. Interestingly, this corresponds to where the above-mentioned "filling the missing links" of the expressway takes place.

With these, several challenges that calls for more research are identified. One of the major challenge is how to better implement the new Basic Act on Transport Policy 2013 so that it can serve as more strategic transport policy interconnecting all of the modes towards intermodal and multimodal transport system at the national level. This is especially important in the current context of the country where rapid aging and population decrease are envisaged on one hand, while on the other hand surrounded by Asian growing economies in the next decades. Another key challenge is to enable more flexible revisions of existing blueprints in line with changing socioeconomic situations: it has been easier to expand the blueprint, while it is politically difficult to shrink it even in the context of the aging demographic structure. A third challenge is to address the current imbalance between the planning systems for railways and expressways. Much research is needed to enable this as it is likely to be a politically fraught process involving the aforementioned revision of the long-term blueprint, as well as creating a proper and reasonable framework for the railway in order to stabilize the existence of regional railways not only based on cost considerations but also considering other socioeconomic aspects.

Open Access This article is distributed under the terms of the Creative Commons Attribution 4.0 International License (http:// creativecommons.org/licenses/by/4.0/), which permits unrestricted use, distribution, and reproduction in any medium, provided you give appropriate credit to the original author(s) and the source, provide a link to the Creative Commons license, and indicate if changes were made.

\section{References}

1. Ministry of Land, Infrastructure, Transport and Tourism (2012) Annual Railway Statistics 2012 (Tetsudo-toukei nenpo for FY Heisei-24)

2. Ministry of Land, Infrastructure, Transport and Tourism (2014) Kuuko-Bunpu-Zu (Map of Locations of Airports)

3. Ministry of Land, Infrastructure, Transport and Tourism (2015) List of port administrators. Tokyo

4. Ministry of Land, Infrastructure, Transport and Tourism (n.d.) Douro-Gyousei-no Kantan Kaisetsu (Summary of Road Administration)

5. Japan Road Association (2014) Douro-no Chouki-Keikaku (longterm planning of roads). Maruzen Publishing, Tokyo

6. Takebe K (2015) Douro-no Nihonshi (history of roads in Japan). Chuko Shinsho, Chuo Kouron Shinsha, Tokyo

7. Iwami Y, Watanabe M (2013) Kuukou-no Hanashi Kaitei-ban (all about airports, revised edition). Seizando, Tokyo

8. Kawauchi H (2010) Nihon-no Koukuu 100-nen-no Rekishi (100 years of civil Aviation in Japan). Kokudo-Koutsu 2010:10-11

9. Kojima H (2012) Jisoku 33km kara Hajimaru Nihon Tetsudou-shi (history of railway in Japan starting at $33 \mathrm{~km} / \mathrm{h}$ ). Asahi Shimbun Shuppan, Tokyo

10. Komuta $\mathrm{T}$ (2012) Tetsudou to Kokka (railway and nation). Kodansha K.K, Tokyo

11. Oikawa Y (2014) Nihon Tetsudou-shi Bakumatsu Meiji hen (history of railway in Japan - Bakumatsu to Meiji period). Chuko Shinsho, Chuo Kouron Shinsha, Tokyo

12. Nakanishi S (2013) Kitamae-Bune-no Kindai-Shi (history o Kitamae-bune) Seizando, Tokyo

13. Kawakami M (2008) Kokudo-keikaku-no Hensen (transition of National Land Planning). Kajima-Shuppan-Kai, Tokyo

14. Ishida Y (2004) Nihon Kingendai Toshi-keikaku-no Tenkai (development of modern urban planning in Japan). Jichitai Kenkyu-sha, Tokyo

15. Hiranuma Y (2015) Haido, Haisen, Miseido, Zuido, Rintetsu, Kokudo - Furuki-yoki Koutsuu-wo Taiken-suru - Yama-sa- 
iganega (Experiencing abandond road and rail, tunnel, forestry railway, and terrible roads) http://yamaiga.com/. Accessed August 2015

16. Miyawaki S (1995) Tetsudou-Haisen-ato-wo Aruku (walking along abandoned railway lines). JTB Publishing, Tokyo

17. Kitahara I (2011) Kanto-daishinsai-no Shakai-shi (Social history of Great Kanto earthquake). Asahi Shimbun Publishing, Tokyo

18. Tsutsui K (2011) Teito-fukko-no Jidai (era of reconstruction of the imperial capital). Chuo-Kouron-Shinsha, Tokyo

19. Sansom G (1963) A history of Japan, 1615-1867. Stanford University Press, Stanford

20. Statistic Bureau of Ministry of Internal Affairs and Communications (Statistics Japan) (2015) Statistical yearbook of Japan (Nihon-no Toukei) 2015. Statistics Japan, Tokyo

21. Ministry of Land, Infrastructure, Transport and Tourism (n.d.) Zenkoku Sougou Kaihatsu Keikaku (Gaiyou) no Hikaku (Comparison of Zensos) http://www.kokudokeikaku.go.jp/ document archives/ayumi/21.pdf. Accessed 10 August 2015

22. Ministry of Land, Infrastructure, Transport and Tourism (2008) Kokudo Keisei Keikaku (Zenkoku Keikaku) (National Land Formation Plan - Nationwide Plan)

23. Ministry of Land, Infrastructure, Transport and Tourism (2015) Kokudo Keisei Keikaku (Zenkoku Keikaku) (National Land Formation Plan - Nationwide Plan)

24. Sato N (2015) Shinkansen-no Rekishi (history of Shinkansen). Chuko-Shinsho (paperback). Chuo-Kouron Shinsha, Tokyo

25. Kado K (2001) Zenkoku Shinkansen Tetsudou-mou no Keiseikatei (the policy making process of Shinkansen railway network program). The annual report on cultural science, Hokkaido University 105:105-134. doi:http://hdl.Handle.Net/ $2115 / 34003$

26. Ministry of Land, Infrastructure and Transport (2005) ShinkansenTetsudo-no-Seibi (Constructions of Shinkansen Railways) http:// www.mlit.go.jp/tetudo/shinkansen/shinkansen6_kanren.html. Accessed 10 September 2015

27. Tanigama $\mathrm{H}$ (2007) The appearance of freight-carrying carts serving as means of transporting Travellers during the late Tokugawa
Shogunate (Edo era) - special focus on precursor vehicle types to the rickshaw on the Tokaido Highway system. Nihon-TaiikuDaigaku-Kiyo 36(2):197-208

28. Ministry of Land, Infrastructure and Transport (n.d.) Kindai-ni Okeru Douro Seisaku (Road Policy in the modern time) http:/ www.mlit.go.jp/road/michi-re/4-2.htm

29. Ministry of Land, Infrastructure, Transport and Tourism (2008) Koukikaku-Kansen-Douro-tou-no Genzai-no Tetsuduki (Current Process for Expressways)

30. Ministry of Land, Infrastructure, Transport and Tourism (2011) Kouwan-no Kaihatsu, Riyou oyobi Hozen, narabini KaihatsuHozen-Kouro-no Kaihatsu-ni-kansuru Kihon-housin (Basic policy and objectives for developments, utilization and maintenance of ports and key see lanes)

31. Japan Aeronautic Association (2001) Minkan-Koukuu Saikai 50nen-wo Kataru (A talk about 50 years of civil aviaition after relaunch) http://www.aero.or.jp/bunka/50zadan.htm

32. Iwatani F (1973) Letters to the editor: the 2nd year plan for aerodrome construction and improvement. J Japan Soc Aeronaut Space Sci 21(231)

33. Ministry of Land, Infrastructure, Transport and Tourism (2013) Koutsuu-Seisaku-Kihon-Hou-ni Tsuite (About Basic Act on Transport Policy) http://www.mlit.go.jp/sogoseisaku/transport policy/sosei_transport_policy_tk1_000010.html. Accessed 22 September 2015

34. Utsunomiya K (2015) Chiiki-Saisei-no Senryaku - Koutsuumachizukuri-toiu apurochi (a strategy for regional revitalization an approach from transit-oriented regional planning). Chikuma Shobo, Tokyo

35. Ministry of Land, Infrastructure, Transport and Tourism (2014) Koutsuu-Seisaku-Kihon-Keikaku (Basic Plan on Transport Policy) http://www.mlit.go.jp/common/001069407.pdf

36. Ministry of Land, Infrastructure, Transport and Tourism (2014) Koutsuu-Seisaku-Kihon-Keikaku-no Suuchi-Sihyo-ni Tsuite (About Key Perfomance Indicators of Base Plan on Transport Policy) 